Predrag Mutavdžić

UDC 316.7:81'246.3(497:4-672)

Faculty of Philology

$316.7: 81 ' 246.3(4)$

University of Belgrade

DOI https://doi.org/10.18485/fid.2017.7.ch7

Jagoda Granić

University of Split, Croatia

Ana Sivački

Faculty of Philology

University of Belgrade

\title{
THE EUROPEAN UNION, THE BALKANS AND MULTILINGUAPHOBIA
}

... leaving one's [language and] culture, while possible, is best seen as renouncing something to which one is reasonably entitled.

(Kymlicka, 1995: 90)

Од оснивања Европске уније, мултикултуралност и вишејезичност су темељи на којима почивају све препоруке и предлози закона о очувању, неговању и ширењу језика и култура на европском континенту. Балкан и Европска унија и даље уче како да се носе са овим различитостима. Идеја о коегзистирању различитих језика је проблем прихваћен од стране народа који су провели векове у грађењу свог идентитета. Како је идеја Европске уније као заједнице различитих језика и народа озбиљно угрожена недавном имигрантском кризом, на мултикултуралност се гледа као на „неуспешан пројекат“ који више раздваја него што спаја. Неке чланице ЕУ и балканске земље неоспорно прихватају вишејезичност, док други не дозвољавају било какву дискусију о томе. Резултат је очигледан - фобија од мултилингвизма. Јавња се питање да ли су сви језици и народи једнаки или је то само једноставна пропаганда под плаштом демократије и наводне демократизације балканских и европских друштава.

Кључне речи: Балкан, Европска унија, фобија од мултилингвизма, разноликост мањина.

\section{Introduction: The European Union and the Balkans}

The European Union as a supranational integration of most European countries certainly is a union of countries (so far there are 28 member states, with a total of 24 official languages), and even if that were desired, 
it could not be established according to Herder's one language - one nation - one country model. It has all the attributes and characteristics of a typical state (territory, population, citizenship, power, 'birthday' - Europe Day, a national anthem, a flag and a currency, but without the Constitutional Treaty, which was rejected after the Dutch and French referendum) - which is why it is sometimes referred to as the Country of Europe or the United States of Europe. The European Union is thus perceived both as an institution and as a system surpassing in this way the scope of an organization for international cooperation. Built on the Franco-German idea of cooperation in 1950, followed by its first enlargement the next year (1951), the very name (concept) The European Union was first mentioned in the Treaty of Maastricht (Treaty on the EU). Amongst many agreements that followed afterwards, we should point out the 1997 Amsterdam Treaty which, among other things, confirmed the plans concerning the Union's enlargement to the East and to the Balkans. This agreement was also focused on the question of asylum seekers and the immigration question - that is on the 'new' minorities, introducing at the same time a clause of suspension, according to which member states could have their rights suspended if they seriously violated the principles of liberty, democracy, respect for human rights (including those language ones) and fundamental freedoms.

As expected, the Union further continues to encourage multiculturalism and multilingualism, as its motto is 'unity in diversity'. Nevertheless, in spite of everything, the linguistic reality differs greatly from the stated goals. English due to its position at the global level - which means outside the Union itself and all over the world - holds a status that even the Union was unable to affect, and that is the English-only status. The European Union could simply confirm this, first implicitly and later on explicitly, when the so-called working languages of the European institutions were established and when it became quite evident that the communication reach of French and German (which follow English, but with a much lower proportion) is less than is the case of English. Whether the Union will remain stable in the future, tightly integrated, or its disintegration will occur - we cannot predict. But the fact is, and this is seen in the diachronic section clearly, that history repeats itself cyclically - from the tower of Babylon to the present day. 
In an attempt to build a multicultural democratic society, Europe has constantly faced numerous problems, including the question of minorities and the frequent migration of European and non-European populations as a result of wars worldwide or poor economic conditions. In the context of language policy of protection of the rights of minorities and promotion of minority languages the majority languages are not excluded; in other words, another kind of monolingualism is not promoted but, on the contrary, bilingualism and multilingualism are being strengthened. Linguistic minorities actually coincide with ethnic/national minorities to whom language is very important in the construction of their collective identity in the territory of the majority community, whether these are indigenous minorities that have lived for centuries in a certain area or allochtonous minorities, ie. immigrants.

Migrations naturally open the problem of ethnicity/nation thus involving collective identities - ethnic and national ones, as well as problems such as linguistic nationalism, linguistic imperialism and linguicism as a result of various phobias, especially due to the inherent, ie. 'Inherited' fear of the Others and the Otherness. Multilinguaphobia is an introduction to linguistic nationalism which in turn is an introduction to 'real' nationalism. Proponents of such ideas usually stress the symbolic function of language as primary by which language becomes roughly instrumentalized and its speakers stigmatized. All these are burning problems which even after they settle down still go on smoldering and if not kept under (political) control can become dangerous and threaten the fundamental values on which the Union is built. Despite all the problems, the European Union is planning new enlargements in the future. However, drawing from the experience, future member states will have to fulfill stringent criteria. This is probably the reason why the Eurosceptics and Europhobes speak of double standards and inequality. But it is also a fact that any new enlargement occurs in a different social and political context that dictates new requirements and modified criteria. On the other hand, possible tensions could perhaps be alleviated if the 'old' Member States are required to reconsider their earlier decisions and align with the existing and/or new charters and conventions thereby eliminating the differences between Member States and thus reduce the impression that some are 'more equal' than others. 
For the Balkan region it could be said that it has always been (and still is!) multilingual well ahead in comparison to a contemporary united Europe and this is the very feature that distinguishes it from the rest of the European continent due to numerous centuries of mutual influences, interweaving and multiplication of cultural, civilizational, linguistic and historical relations. The final result has been a form of very well built up and recognisable Balkan Weltanschauung relatively distinctive both among all modern Balkan nations and members of different minority communities. Looking at the general level, we can speak about the existence of a common Balkan awareness and about a unique Balkan culture, irrespective of religious and civilizational background.

If we were to make the effort to answer the question of how many Balkan languages there are today, we would encounter obstacles. To give a completely accurate and reasonable response to this question is, conditionally speaking, as hard as to say exactly how many nations, minorities and ethnic groups there are in each Balkan state. The reason for this lies in the fact that the contemporary Balkan linguistic picture is riddled with complex daily political and strong national and nationalist aspirations which further complicate the situation. The disintegration of Serbo-Croatian/ Croato-Serbian, which culminated in the 1990s and which (hypothetically speaking) ended in 2007, with the proclamation of Montenegrin as the official language of Montenegro, shows the feedback between the above elements. At the same time, it has demonstrated how a language can be burdened with nationalist, ideological and emotional layers. Furthermore, one should not forget the many (political and primarily economic) pressures coming from the side, particularly those from the European Union, who have conditioned a gradual change in the language policy of each Balkan country towards the speakers of minority languages. Nevertheless, all these pressures have not been fully successful. One of the reasons is still hidden in the definition of the concept of minorities, i.e. in the variety of its interpretations. The problem is even greater when a minority needs to be characterized as indigenous or allochthonous since it is about different ranges of language and of all other rights.

Additional language disintegrations in the Balkan linguistic area are also influenced by other factors the features of which are mainly of a socio- 
linguistic nature and which are related to the fact how an individual or a community, perceives himself/itself in relation to other similar or separate linguistic ones. The role of language in this case comes down to a specific marker of their individual ethnic identity, which, consequently, highlights the cultural and civilizational one. Edwards (Edwards, 1985: 6) once proposed the consideration of the ethnic identity of a nation and/or minority in two ways, perfectly reasonable and acceptable according to him:

I. objective, which would take into account the so-called 'stable' factors, such as language, religion, race, geography, terrain and cultural heritage, and

II. subjective, through factors extremely susceptible to changes in an environment, since they are based on voluntary segments and go somewhat more into the domain of collective beliefs and attitudes (which often touch upon prejudices and juxtapositions).

Something similar has previously been underlined by the American linguist Ferguson: "in every speech community attitudes and beliefs about its language exist such as those about other languages and about language in general. Some are true, that correspond to objective reality, some include aesthetic and religious concepts whose validity cannot be empirically tested, and some are quite wrong, in whole or in part "(Ferguson, [1959] 1968: 375). When it comes to the modern Balkans, interweavings between the objective and subjective elements is so complex that it is sometimes difficult to draw a precise line of demarcation between them. On the territory of the former Yugoslavia, in relation to the whole Serbo-Croatian spoken area, subjective and objective factors completely pulled aside Slovenian and Macedonian. Following its demise, it became quite evident that the idea of the existence of a unique language form had not been an objective factor, even less stable, while religion and cultural heritages were not considered strong enough to frame a common (Yugoslav) collective identity.

\section{Knowledge of a language or languages?}

There is an old saying in almost all European languages - the more languages you know, the more you are human. It seems that it had anticipated a need of foreign language learning and, consequently, spread in 
social environments long before all of modern European laws, charters and recommendations of the linguistic rights of minorities and communities. However, no matter how democratic, human and universal this statement is by its nature, it certainly raises a question. If knowledge of foreign languages has always been important, and in some cases quite crucial for the survival of individuals and nations, why have all foreign languages not been taught on a broader scale? Or, to rephrase the question - if knowledge of foreign languages has a great value and power, why are all the foreign languages not learnt to an equal extent? Perhaps the question seems tautological, but it is deeply motivated by a factual situation clearly visible in the today's Balkans and in the EU - only a limited number of languages has been favored primarily from numerous extralinguistic reasons (from which have emerged attitudes to each language, which are, of course, arbitrary) in relation to all the other ones. It is true that all languages cannot be known and learnt as it is true that in the Balkans there is only a small number of people who speak foreign, hence Balkan, languages. Although the aforementioned saying is absolutely correct in its essence and in the spirit of altruism, the social practices of the Balkan and European nations directly refute it, because "every language still does not have its prestige" (Friedman, 1997: 32-35).

In other words, although it is necessary to know foreign languages, each society independently decides (doesn't it?) which languages should be recognized as acceptable and, consequently, prestigious. To give just one example, due to political, religious, social, traditional, cultural and other reasons in all Balkan societies there has always been a natural tendency towards learning one modern world (European) language - either German, French or Russian, and (since the end of the Second World War, English as well) - but not any contemporary Balkan one. Seen from the point of view of prestige, it is a historical fact that no contemporary Balkan language in any Balkan society from the nineteenth century onwards has been valued as prestigious or important. Therefore, it is quite obvious that Balkan languages, including modern Greek have mostly been studied at the university level (here in the Republic of Serbia mainly the Faculty of Philology in Belgrade) for socio-political reasons, and later from economic and cultural ones. The abrupt turning of Balkan societies towards 
the Greek language was motivated by the fact that since the end of the cold war Greece has been the only country member of the EEC in the Balkans but also a leading economy, which, as the most developed Balkan country, has seen its interests in encouraging the economic development of the entire Balkans further integrating it into the later European Union (Gligorov et al., 1999: 31-39).

For this reason, the Hellenic Plan for the Economic Reconstruction of the Balkans was designed in 2002 with substantial financial support from major Greek banks. To achieve this plan from the long-term vantage point, it was necessary to further strengthen the already existing studies of the Modern Greek language in Balkan nations. The latter opening of cultural centers of the Hellenic Fund by Balkan countries (in Sofia, Belgrade, Bucharest) has further underscored the expansion of the Greek cultural, economic, industrial and civilizational element. At the same time, the historical reminder of the importance of cooperation with Greece in the formation of the anti-Turkish coalition at the beginning of the twentieth century and the role that Greece offered the Serbian army after its withdrawal through Albania in the First World War have been some of the most important elements to additionally encourage the Serbian side to turn towards Greece and to accept learning Modern Greek on a wide scale, primarily at institutional (university) level. Nevertheless, let us point out that so far such reciprocity has not been introduced at any Greek state educational institution by establishing departments or centers for learning Balkan languages. The experiment with the outpost of the University of Macedonia in Florina, where students of economics and management were offered a possibility to learn one Balkan language and Russian as well as a language of choice in the period of two years has failed, especially from the moment when Greece was hit by economic crisis which prevented further funding of this project. This means that it is up to individuals whether and how they will learn Balkan languages, if they are in such a need.

When observing the ethnic structure of modern Balkan states, we can see the following picture. According to all official statistics from the census of 2011, in Greece there is no category of minority languages - as many as $95 \%$ of people reported Greek as their mother tongue - due to the fact that the possibility of stating another language was omitted in the 
survey. Almost a mirrored situation is observed from the census in Albania $-98.76 \%$ of the population said that their mother tongue is Albanian (Census, 2011: 73). The question of the existence of minorities and ethnic groups in both countries has not been considered at all. Perhaps the best example of this would be the position of Aromanians that the Greek side considers Greeks - crucial here is the religious and civilizational context, since all Aromanians in Albania are members of the Greek Orthodox Church and speak Greek together with Albanian. The Albanian side also regards them as Greeks, while the Aromanians still identify themselves as a separate ethnic, cultural and linguistic community. However, the Albanian authorities do not recognize Aromanians as a separate minority or community, hence all those who identified themselves as Aromanians were automatically classified as members of the Albanian population. In Bulgaria the census has showed that the Turks are the second national community in number and as a consequence they were recognized, but Turkish as a minority language was not. In early 2000, the Bulgarian National Television broadcast a program in the Turkish language which was soon canceled. After the 2009 elections, when representatives of the Turkish parliamentary party again raised the issue of broadcasting in Turkish in the parliament, there was a violent reaction from deputies of the nationalist Ataka Party who prevented any possibility of presenting such proposals for consideration or a vote with inappropriate speeches at the podium and statements given for TV stations. This negative attitude was echoed uncomfortably in the European Parliament so an urgent explanation was demanded from the Bulgarian parliamentary representative Rumyana Zheleva. Her answer was absolutely in line with such a negative attitude and behaviour: "It is not possible that the majority be terrorized by the inappropriate demands of a minority."

\section{Balkan multilinguaphobia}

Fear of the presence of 'the others' on 'our own territory', in addition to nationalism, chauvinism and antagonism, certainly entails the fear of even the possible existence of a language (or languages) 'different from ours'. In fact, these two fears are always coupled together and cause negative attitudes among the majority towards a minority. According to Todor- 
ova, "nationalism in the Balkans in the nineteenth century was constructed primarily around linguistic and religious identities" (Todorova, 1999: 176), which is a correct observation, since a strong coupling between nations, languages and countries, ie. territory was (and still is!) incorporated in the creation of modern Balkan states. This ethno-linguistic attitude was among the first contested by Sapir, saying that "totally unrelated languages they share in culture, closely related languages - even a single language - belong to distinct cultural spheres" (Sapir, 1921: 213). The fact is that the current ethno-linguistic stream is rooted within Herder's views on language, nation and country (Bauman-Briggs, 2003; Blommaert, 1999; Kroskrity, 2000; Silverstein 2000). To be more precise, his points and perspectives were unfailingly accurate at the very end of the eighteenth century, but the truth is usually neglected that Herder was an ideologist of the German young bourgeoisie to whom the existence of many small independent German states (and boundaries between them) was not acceptable, especially in the economic and commercial mindset, as such small political entities could not have been players on the world scene and could not have caught up with all the innovations in techniques, science and technology - let us remember that it was perhaps the main reason why the United Kingdom had managed to take control over the vast areas of our planet, since it did not have an equal competitor. Very quickly Herder's ideas were adopted and, almost in the same mold, applied among other nations, including all the Balkan ones.

In this respect, the affirmation of a linguistic patchwork of the traditional, historical and ethnic (imaginary) space at the beginning of the formation of contemporary Balkan states was a priori rejected as a possibility. Any form of linguistic diversity different from the majority one was perceived as a great danger for the country and nation, as there was always a possibility that the newly established national and territorial unity could be easily endangered. The structure of the population of the Balkan countries which were gradually expanding at the expense of the weakened Ottoman Empire included many members of different ethnic communities. All of them were given the possibility to leave the country, as most did, but those who remained, for various reasons, were subjected to strong assimilation into the majority. If they could not be converted religiously, although there were such attempts in Bulgaria and Greece, for example, the 
authorities tried linguistically prohibiting (less often restricting) the use of their mother tongues in everyday communication, imposing harsh penalties for violating those law provisions. From the political and national point of view, bilinguals in the Balkan countries during the nineteenth and twentieth centuries were regarded as 'extremely uncertain factors' whose loyalty was openly suspected. Officially propagated monolingualism was modified in the course of time. The merging of Vojvodina into the Kingdom of Serbs, Croats and Slovenes in 1918 conditioned the acceptance of existence of multilingualism, as large populations of Germans, Hungarians, Czechs, Slovaks and Romanians joined the newly established state, whose knowledge of Serbo-Croatian/Croato-Serbian was not sufficient. On the other hand, a different policy was followed in Macedonia - the Macedonian language, regardless of its obvious existence, was completely ignored, suppressed and even negated, in which the Yugoslav government was supported by the Bulgarian side. The same can be said for Albanian.

After the Second World War in the Balkan countries, with the exception of the former Yugoslavia, language policy based on the propagation of absolute monolingualism remained completely unchanged. In the former Yugoslavia multilingualism was represented at the official level - pursuant to the provisions of the Constitution, Slovenian and Macedonian together with all minority languages - Albanian, Hungarian, Romanian, Czech, Slovak were equally used in addition to the Serbo-Croatian/Croato-Serbian. In this respect, Yugoslavia was a true conglomerate of multilingualism, but in practice the domination of major Serbo-Croatian/Croato-Serbian was visible, whose speakers were conditionally speaking the 'privileged' language and were excused from learning other (i.e. minority) languages. In all nationally mixed areas such as Vojvodina and Kosovo and Metohija, teaching in schools took place in the majority language of these communities (Hungarian, Romanian, Albanian), while pupils had the obligatory learning of Serbo-Croatian which by subsequent reforms of the educational system became optional and at the very end was completely abolished. The identical situation existed in the areas where Serbo-Croatian/ Croato-Serbian was spoken - minority languages were initially mandatory and then optional to pupils, only to be eventually canceled. All this resulted in a parting of the ways for members of different nations and minorities in 
time, including in linguistic terms. Thus, for example, in early 2012 a sensational piece of news was published - in our opinion, extremely alarming from the linguistic point of view! - that young generations from Subotica, either from the majority Serbian or Hungarian environment communicate among themselves exclusively in English. Insufficient knowledge or ignorance of the other's language is bridged by the use of English as the (global) contact language. Although the official educational authorities of Vojvodina immediately denied these allegations, characterizing them as very tendentious and malicious, we believe that the truth is actually somewhere in between bearing in mind the proverb 'there is no smoke without fire'.

The accumulated negative cultural-civilizational, historical and national attitudes and prejudices of neighboring Balkan nations are the result of objective ignorance of the others, on the one hand, and excessive glorification of their own historical, cultural and other achievements, on the other. This relation, which included the closure of the Balkan nations and their societies within their ethnic boundaries, caused the crystallization of a general antagonistic image from the Middle Ages onwards, within which each Balkan language had assumed its so-called primary position. Even today it is often heard in Serbia "speak Serbian so that the whole world can understand you"; in Greece it is still generally accepted as fact that the Greeks "have given vocabulary throughout Europe and the world"; in Albania only Albanian is "the most melodious language" (gjuha sa e ëmbël); while in Bulgaria it is believed that Bulgarian is "the source of all Slavonic languages". In the modern times, which inevitably entail much closer and tighter links and cooperation between all nations, such 'incidents' do not fit into the idea of European multiculturalism and multilingualism. Nevertheless, such attitudes are not only typical of the Balkans. The French writer Claude Gagnier (1928-2003) said on one occasion: "Un homme qui parle trois langues est trilingue. Un homme qui parle deux langues est bilingue. Un homme qui parle qu'une langue est Anglais”. His opinion is really true, since it points to the continuing lack of interest of the Englishmen to learn foreign languages - as English has become the universal language of planetary communication it is absolutely unnecessary to learn any foreign language because wherever you go, you feel "as if you were in your own home". 
On the other hand, if we possess competence in any other language(s), but assuming that none of them is English, we shall be equally considered 'illiterate' because we do not know English. It is certain that a hypothesis based on saying "the more languages you know, the more you are human" cannot be true as our lack of ability of communicating in English clearly 'deletes' our competencies in other languages, owing to the prestige that English has had on the global level as a lingua franca. English has become the first foreign language in almost every curriculum in Europe and worldwide. According to Ostler (Ostler, 2010), on the list of the world's largest languages English is in the first place because for more than 330 million speakers it is a mother tongue while for over 810 million speakers English is the lingua franca. Therefore, it is very difficult to speak of linguistic equality in these circumstances, if we take into consideration the relation of English and all the other majority and minority languages which also seek to find their place in the realms of discourse and public communication. But when it comes to a different linguistic picture, when looking at the relations between existing languages in a particular environment, region or country, then the linguistic map and the issue of linguistic equality between majority and minority languages is in the domain of national and supranational (European) language policy and such kind of problems are to be quickly dealt with.

In the twenty-first century it sounds almost unbelievable that the question of linguistic equality has not been positively resolved in all the Balkan societies in spite of numerous European and international charters, documents and recommendations that have meanwhile been signed and ratified by some governments of the Balkan countries. Namely, Bosnia and Herzegovina, Montenegro, Romania and Serbia have signed and ratified the European Charter for Regional and Minority Languages. Macedonia has also signed it, but it has not been ratified yet. Neither Albania, Bulgaria or Greece, two of of them members of the European Union, have signed or ratified the document, which implies, diplomatically speaking, a complex situation of minority languages in those countries, regardless of the monitoring of the European Union. Another equally important European document - the Framework Convention for the Protection of National Minorities concerns the very linguistic rights. Both documents came into force 
in 1998 underlining the importance of preserving linguistic diversity (the Charter) and linguistic rights (the Convention), but only of the autochthonous languages, while the allochthonous ones have not been even mentioned. It is worth noting that Greece, as a Balkan country and as a member of the European Union, has only signed but not ratified the Framework Convention for the Protection of National Minorities. All other Balkan countries have signed and ratified the document.

However, as in the Balkans numerous unresolved national, historical, and religious problems are still smoldering, and the attitudes to each other's language should not and cannot be surprising. The ever-so-present scars inflicted during the political-religious conflicts and wars in the 1990s reinforced the nationalistic views in the southern Slav-speaking area and directed attention to each community's own linguistic expression which, in accordance with the aspirations, has been re-worded in the name of their language. As a result there has been no place for the other one(s) until recently. In any Balkan, European, and even world environment there prevails a natural tendency for the dominant language group to directly control all key social elements (education, economy, administration, etc.) essential for normal state functioning. Anyone who knows the dominant language (to a satisfactory or very good extent) has got a (relatively limited) access to them. As Nelde (1997) properly noted, "other language groups are limited in their language use to specific domains, usually solely private and/or low status and are thus left with the choice of renouncing their social ambitions, assimilating, or resisting in order to gain greater access to the public realm". Results of recent research on the use of Albanian in contemporary Belgrade have corroborated this very fact while pointing to a somewhat limited number of domains in which Albanian is spoken and emphasizing a rather institutionalized and compartmentalized use of this Balkan language in Belgrade (cf. Mandić-Sivački: 2015)

\section{Conclusion: New models of language policy?}

In the Balkan societies, Balkan languages are still stigmatized in one way or another, maybe not so visibly with the open support of the state and

its institutions, but mostly with the support of the national collective that 
has not yet matured in general linguistic terms. Seen from the ideological point of view, there is still no awareness of the fact that every modern Balkan language is equally valuable and important just like any of the other (major, world) languages which are taught in the Balkan states as foreign languages. In the eyes of linguists, all languages are equally valid, and even those with the lowest communication range. Nevertheless, the fact is that the speakers apparently choose languages themselves under the influence of the 'market', economically speaking. This, of course, is not the Martinet 'linguistic economy', but it certainly is an economic, pragmatic reason. English as a global language 'opens the doors' of communication anytime, anywhere and with anyone. Major world powers, economic power, politics and the media, culture, science and sport have done their own by 'favouring' some languages, in particular English, which has become the contact language of the modern world.

On the other hand, and as direct practice in the European Union shows, linguistic diversity is indeed a major obstacle in unrestrained communication (Gal, 2006; Moore, 2011), thus confirming Bloomfiled's entirely correct observation that the boundaries between the different linguistic communities always coincide with the "lines of weakness in communication" (Bloomfield, 1933: 47). In the Balkans, perhaps far more than in the European Union, the limits and weaknesses of communication have been strongly manifested as the Balkan societies are still monolingual - in all of them the linguistic hegemony of the official language is forced, and society does not play the role of a supranational cohesion symbol but is rather a strict ideological basis in the form of solid linguistic awareness of the absolute use of the language. Hence, the majority language is not semioticly neutral, while for all the other languages it may be said that they are neither desirable nor essential. In addition, all linguistic ideologues and planners of the Balkan languages were not native speakers thereof and they observed the language only from their narrow (regional) point of view. Contrary to them, for example, as Gal points out, some of the most distinguished ideologues of the modern Hungarian language were not native speakers of Hungarian so they tried to create such Hungarian which would belong to all its speakers. In other words, it was a linguistic system (idiom) which was not attached (or, better to say, attributed) to any kind 
of social group or specific region (Gal, 2001: 33, 43). In his works, the French linguist Bourdieu calls the Balkan, and indeed European linguistic authority of the official language a 'misrecognition' (in French: méconnaissance; Bourdieu, 1982; Bourdieu, 1991), which has enabled the linguistic hegemony of only one language. According to Woolard, "the concept of misrecognition tells us that the standard is not really everybody's language, and that it really does belong to specific 'someones' more than to others" (Woolard, 2008: 308).

In this way the sharp polarization between the majority language and the languages of minorities is instigated and nurtured. On the one hand, it is quite logical to accept this dichotomy, especially in a country such as Serbia where in one of the parts of its territory five official languages are equally used (Croatian, Hungarian, Romanian, Ruthenian and Slovak) together with three minority languages (Czech, Macedonian and Montenegrin). Of course, it is not impossible to acquire competence in all these languages, but it is certainly harder to achieve it in the case of unrelated languages. On the other hand, if we look at the need to learn languages, especially from the perspective of multiculturalism, multilingualism and intercultural communication, then it is quite justified to challenge the linguistic hegemony of the dominant language which requires political readiness and the will of the majority community (nation). The majority communities in the Balkan peninsula which consider language as a part of their cultural tradition, dedicated a good part of the nineteenth century and almost the entire twentieth century to creating their own monolingual and monocultural environments in which there was no place for 'others'. Nowadays, in the second decade of the twenty-first century this historical throwback is very difficult to change not only in the Balkans, for which necessary preconditions are required, above all a radical change in mindset and historical relations with neighboring nations.

Despite explicitly expressed animosity towards multiculturalism and multilingualism by some of today's most prominent European politicians and MEPs, and in spite of this multilinguaphobia, minority language rights are still expanding nowadays. Will Kymlicka (2001) believes that it is a defensive reaction to the construction of the nation-state and its assimilation policy, but additional reasons also lie in various aspects of post-national 
globalization as well (Wright, 2004). Bearing in mind that nationalism $a$ priori rejects the use of minority languages in (any form of) public communication, the majority insisting on the active use of its language should change and moderate its language policy without neglecting or giving up its national identification but letting the others express their national identification and their linguistic identity. Only when we open our views does fear of others together with fear of the loss of our power disappear, especially if we try to acquaint ourselves with both the language and culture of the Other. And this could be possible if new language policy models based on universal (human) values were defined and, of course no less important, implemented in practice.

\section{References:}

Bauman, R. \& Briggs, C. (2003). Voices of Modernity. Cambridge: Cambridge University Press.

Bloomfield, L. (1933). Language. New York: Henry Holt.

Blommaert, J. (ed.). (1999). Language ideological debates. Berlin: Mouton de Gruyter.

Bourdieu, P. (1982). Ce que parler veut dire; L'économie des échanges linguistiques. Paris: Fayard.

Bourdieu, P. (1991). Language and Symbolic Power. Cambridge, MA: Harvard University Press.

Censusi (2012). Censusi i popullsisë dhe banesave 2011/Population and Housing Census. Resultatet Kryesore/Main Results. Pjesa/Part 1. Tiranë: Instituti i statistikës.

Edwards, J. (1985). Language, Society and Identity. Oxford: Balckwell.

ELSTAT (2013). Greece in Figures 2013 (Piraeus: Hellenic Statistical Authority).

Ferguson, Ch. ([1959] 1968). Myths about Arabic. Languages and Linguistic Monograph Series, 12, 75-82. [Reprinted in:] Fishman, J.A. (ed.). Readings in the Sociology of Language (pp. 375-381). The Hague-Paris: Mouton.

Friedman, V.A. (1997). One Grammar, Three Lexicons: Ideological Overtones and Underpinnings in the Balkan Sprachbund. In: Singer, K., Eggert, R. \& Anderson, G. (eds.). CLS 33: Papers from the Panels on Linguistic Ideologies in Contact, Universal Grammar, Param- 
eters and Typology, The Perception of Speech and Other Acoustic Signals (pp. 23-44). Chicago: Chicago Linguistic Society.

Gal, S. (2001). Linguistic theories and national images in nineteenth-century Hungary. In: Gal, S. \& Woolard, K.A. (eds.). Languages and Publics (pp. 30-45). Manchester: St. Jerome.

Gal, S. (2006). Contradictions of standard language in Europe: Implications for the study of practices and publics. Social Anthropology, 14 (2), 163-181.

Gligorov, V., Kaldor, M. \& Tsoukalis, L. (1999). Balkan Reconstruction and European Integration. The wiiw Balkan Observatory, Working Papers 001 (October 1999). (cited from:

http://www.google.rs/url? sa=t\&rct=j\&q=\&esrc=s\&source=web $\& \mathrm{~cd}=1 \& \mathrm{ved}=0 \mathrm{CBwQFjAA} \& u r l=\mathrm{http} \% 3 \mathrm{~A} \% 2 \mathrm{~F} \% 2 \mathrm{Fwiiw}$. ac.at\%2Fbalkan-reconstruction-and-european-integration-dlp 3354. pdf\&ei=cU1IVeTrGIr0UJ_HgMAI\&usg=AFQjCNG17_cMEorXugx8EYi0nY-efV9OYQ, last visited: May, 5th, 2015)

Kroskrity, P. (ed.). (2000). Regimes of Language. Santa Fe: School of Advanced Research Press.

Kymlicka, W. (1995). Multicultural Citizenship: A Liberal Theory of Minority Rights. Oxford: Clarendon Press.

Kymlicka, W. (2001). Politics in Vernacular: Nationalism, Multiculturalism and Citizenship. Oxford: Oxford University Press.

Lazarova, A. \& Rainov, V. (2011). On the minority languages in Bulgaria. In: Stickel, G. (ed.) National, Regional and Minority Languages in Europe. Duisburger Arbeiten zur Sprach- und Kulturwissenschaft/ Duisburg Papers on Reseach in Language and Culture, Band/Volume 81. (pp. 97-106). Frankfurt am Main: Peter Lang GmbH.

Mandić, M. \& Sivački, A. (2015). Jezik i etno-politički sukob: Slučaj albanskog u savremenom Beogradu. In: Pavlović, A. et al. (eds.) Figura neprijatelja: preosmišljavanje srpsko-albanskih odnosa (pp. 261282). Čačak: Print Solutions (Edicija TonB).

Moore, R. (2011). Standardization, diversity and Enlightenment in the contemporary crisis of EU language policy. King's College London Working Papers in Urban Language and Literacies 74. (<https://scholar.gse.upenn.edu/moore/files/moore_2011d_eu_language_policy_kcl_wp.pdf) 
Nelde, P.H. (1997). Language conflict. In: Coulmas, F. (ed.) The Handbook of Sociolinguistics (pp. 285-300). London: Blackwell.

Ostler, N. (2010). The Last Lingua Franca: The Rise and Fall of the World Languages. London: Penguin Books.

Phillipson, R (2003). English-Only Europe? Challenging Language Poli$c y$. London-New York: Routledge.

Sapir, E. (1921). Language: An Introduction to the Study of Speech. New York: Harcourt, Brace \& Company.

Silverstein, M. (2000). Whorfianism and the linguistic imagination of nationality. In: Kroskrity, P. (ed.). Regimes of Language (pp. 85-138). Santa Fe: School of Advanced Research Press.

Woolard, K.A. (2008). Language and Identity Choice in Catalonia: The Interplay of Contrasting Ideologies of Linguistic Authority. In: Süselbeck, K., Mühlschlegel, U. \& Masson, P. (eds.) Lengua, nación e identidad. La regulación del plurilingüismo en España y América Latina (pp. 303-323). Frankfurt am Main: Vervuert/Madrid: Iberoamericana.

Wright, S. (2004). Language Policy and Language Planning: From Nationalism to Globalisation. New York: Palgrave Macmillan.

\section{Sources:}

http://www.omoilindenpirin.org/documents/report.pdf

http://www.blic.rs/Vesti/Vojvodina/302646/Razumeju-se-samo-naengleskom-jeziku

http://www.omoilindenpirin.org/documents/report.pdf

https://scholar.gse.upenn.edu/moore/files/moore_2011d_eu_language_ policy_kcl_wp.pdf

http://www.theguardian.com/uk/2006/dec/03/schools.education

http://www.bbc.co.uk/news/education-15189033

http://www.theguardian.com/education/2013/sep/11/uk-languagesteaching-crisis

http://www.unece.org/fileadmin/DAM/operact/Technical_Cooperation/ Greek_Development_Cooperation.pdf 


\begin{abstract}
Since the establishment of the European Union, multiculturalism and multilingualism have been the foundations upon which rest all recommendations and legislative proposals on preserving, fostering and expanding the languages and cultures of the European continent. The Balkans and the European Union are still learning how to cope with this diversity. The idea of coexistence of different languages is difficult to accept for nations which have spent centuries building their own identity. As the idea of the European Union as a community of different languages and nations has been seriously threatened by the recent immigrant crisis, multiculturalism is looked on as a 'failed project' that divides rather than unifies. Some EU members and Balkan states unquestionably accept multilingualism, while others do not allow any discussion about it. The result is obvious multilinguaphobia. The question arises as to whether all languages and nations are equal or is it just simple propaganda under the guise of democracy and of alleged democratization of Balkan and European societies.
\end{abstract}

Keywords: Balkans, European Union, multilinguaphobia, diversity, minorities.

\title{
Biographical statement
}

PREDRAG MUTAVDŽIĆ, PhD, is an assistant professor of comparative Balkan Linguistics at the Department of Modern Greek Language and Literature (Faculty of Philology, University of Belgrade) graduated from two departments of the Faculty of Philology (Department of Albanian, Department of Modern Greek). His main research interests are focused on phraseology, on contemporary historical development of the Modern Balkan Languages and on their morphosyntax. His interests are based on cross-culturalism and multilingualism, on teaching of modern Balkan languages, on Balkan idiomaticy, on history and on relations among the Balkan nations in synchronic and diachronic perspective.

E-mail address: predrag.mutavdzic@fil.bg.ac.rs

JAGODA GRANIĆ is Assistant Professor in Linguistics at the University of Split (Croatia). has graduated in General Linguistics and Phonetics and received her MSc and $\mathrm{PhD}$ in Linguistics from the University of Zagreb. She has participated in many research projects and presented 
papers at more than sixty international conferences. She has published numerous papers in different fields of linguistics, especially interested in theoretical linguistics, applied linguistics, pragmatics and sociolinguistics. She is a specialist in language policy and language rights, focused on minority and majority languages in the EU. Member of many professional organizations dealing with multilingual matters: LINEE+ (Languages In a Network of European Excellence), ENIEDA (The European Network for Intercultural Education Activities), ELA (The Eurolinguistic Association). She has organized several international conferences. She is a past President of the Croatian Applied Linguistics Society (CALS) and the editor of several volumes such as Language and Identities, Language and the Media: One Language : Many Worlds, Language Policy and Language Reality etc.

E-mail: jagoda.granic@gmail.com

ANA SIVAČKI graduated from the Faculty of Philology, University of Belgrade (Department of Albanian Language and Literature) and holds an MA degree in Albanian. As a $\mathrm{PhD}$ candidate she is working on her thesis in contrastive Albanian and Serbian phraseology, while she is also a full-time translator with more than a dozen published translations. The main topics of her current research and interest include contrastive Albanian and Serbian phraseology, contact linguistics and foreign language acquisition. So far, she has published a large number of scientific papers in various books of proceedings and scientific journals.

E-mail: anasivacki@yahoo.com 